\title{
Study on the Art Form and Regional Characteristics of Yimeng Folk Cloth Handcrafts
}

\author{
Lijuan Feng \\ Primary Education School \\ University of Linyi \\ Feixian County, Shandong, China 273400
}

\begin{abstract}
As an important component of the Yimen's regional culture, the Yimeng folk cloth handcrafts are deeply rooted in the fertile Yimeng culture, blended with Yimeng's regional unique history, culture, customs and arts of the people, showing a unique beauty of craft characteristics and connotation. In the current cultural context, to study the Yimeng local cloth works art form and content and its regional characteristics and to explore its art value and humanity implication is of important reality significance in excavating the Yimeng culture, protecting and inheriting outstanding folk arts and crafts.
\end{abstract}

Keywords_Yimeng; folk cloth handcrafts; regional characteristic; cultural connotation

\section{INTRODUCTION}

The Yimeng folk handcrafts are one of the forms with the most aesthetic characteristic. It has become the carrier expressing Yimeng people's aesthetic emotion and artistic spirit for its road mass participation, distinctive regionalism and aesthetic characteristics. It originates in the folk and serves the common people, and appears in the people's daily life, beliefs and customs, etiquette and taboos. Its unique artistic form and distinctive aesthetic qualities have made a profound influence on the life of people.

\section{MAIN ART FORM}

The Yimeng area is rich in folk handcrafts resources and art forms. Such cloth works are widely distributed in nine counties and three districts of Linyi city. Currently more than a dozen of kinds of cloth works have been registered with the city-level and county-level cultural management authorities. To distinguish them in term of craftsmanship, materials and functions, there are several types such as printing and dyeing products, embroidery, dress, toys and various kinds of fabric ornaments.

\section{A. Folk Dyeing}

The Yimeng's folk dyeing craftsmanship originated a very long time ago, with its history dating back to the Spring and Autumn Period. In the art form, Yimeng's printing and dyeing is mainly divided into two major types: "blue printing" and "colored printing". The blueprint cloth mainly adopts dyeresistant technology one plate missing print, which uses plant indigo as dye, through base contrast to make cloth present simple blue ground with white flower design or white ground with blue flower pattern. Color printed cloth is made on oil paper engraved blocks for printing through multi plates overprinting, showing exquisite and intricate patterns and beautiful colors. In the past in the Yimeng Mountain, the folk printing and dyeing was extremely widely used. . People's daily clothes, quilt covers, cloth-wrappers, curtain, kerchiefs and so on were all hand printed by folk artists. The blue cloth with design in white and color printing cloth in Yimeng once became symbol of Yimeng dress culture and regional style for its full-bodied local feature. At present, with the improvement of people's living standards, the traditional folk printing and dyeing has gradually faded out of people's life, and has turned into a kind of pure artwork showing a higher technology and aesthetic value. Among these products, the color printing cloth from Hedong and the blue cloth with design in white from Cangshan Dazhong village, etc, have become a typical representative of the Yimeng folk dyeing technology for its strong local characteristics, unique aesthetic value and exquisite technology.

\section{B. Folk Embroidery}

The Yimeng folk embroidery has long enjoyed good reputation for its variety of form, fine skill and bright color. It has extremely extensive mass foundation. In the past in Yimeng Mountain, the bride wedding dress, pouch and presented as gift to friends, pillows, curtains, handkerchiefs, etc. used in daily life, were all embroidered by hand of handicraftsman with thousands of threads. The Yimeng embroidery also became local women's important "needlework" skills fir its exquisite craft and the rich humanities meaning. As one of Lu embroidery, Yimeng embroidery inherits the local folk traditional handwork method. It uses colorful double strand clothing threads as embroidering threads to embroider patterns in plain or dark color bottom lining with such needling methods as aligning, twining, etc, thus forming a graceful composition, elegant image, fresh color and gorgeous unique artistic style. Among these works, the hand embroidered works from Yishui Gaoqiao Town are quite famous for its three-dimensional shape, vivid color and exquisite decoration of nail and tassels. Now the works are collected by many museums of art. The embroidered insoles from the areas of Mengyin and Feixian County are in simple, natural and exquisite patterns, with strong local flavor. The fragrant pouches from Junan and Lanshan are seldom- 
encountered adornment in the local people living for its exquisite embroidery skill, elegant color and rich auspicious meaning.

\section{Traditional Dress}

The Yimeng folk handcrafts have many kinds, in which the bride wedding dress and children's clothing are the most regional characteristic. The bride wedding dress in Yimeng is traditional clothing dressed by bride at her wedding party and usually it is hand made by the bride, sent by her husband's family just several days before marriage to the bride's house. It is called "urging the marriage". The bride wedding dress includes cloud shoulder, head cover, skirt coat, embroidered shoes, etc, with the patterns symbolizing the harmonious and happy life of couples such as dragon and phoenix, mandarin duck, pomegranate and peony, lotus, goldfish, etc , Ornaments are complicated and exquisite, colorful celebrations, with strong local flavor and decorative means. Yimeng' children's clothing includes the dress made of lots of pieces of cloth begged from one hundred peasants, tiger-headed shoes, colored chest cover. They are usually used as gifts presented at the party when the children are one month old or one year old. The Children's garments are made of multi colored cloth and are connected by color line, with exquisite embroidery decoration and auspicious, colorful patterns, to show "longevity, eternal peace" blessing from the elders to children.

\section{Cloth Toys}

In Yimeng, the cloth toys are made of silk, cotton, linen or by natural stuffs, added by embroidery, hanging beads, etc. With exquisite modeling, soft texture, bright color, they are not only toys played by children as their intimate partner, but also are kind of arts and crafts with very artistic appreciation value. Yimeng cloth tiger is one of the most common folk cloth toys. The main materials are edges or pieces of cloth, cotton, hemp, etc. They are filled with bran, cotton, silkworm excrement, artemisia argyi, cinnabar tec. The material is natural and colorful. They bear lucky implied meaning. So they are the best gifts given by parents to give children in Yimeng. The embroidered cloth balls popular in Junan and Lanshan area are very famous in that place for its complex shape and exquisite embroidery and are children's favorite toys and decorations. In addition, the cloth lantern of Feixian County and the spring chicken and cloth baby of Pingyi County are outstanding representatives of Yimeng cloth toys for its unique style, exquisite workmanship and rich local style.

\section{E. Modern Decorative Cloth Works}

Modern decorative cloth refers to a kind of cloth product made of all kinds of textiles, with some modern elements in art processing, with a certain decorative effect to meet the aesthetic needs of people. Relative to the traditional folk art, Yimeng's modern cloth art work material appear in more varieties, with more diverse techniques. It breaks the traditional folk art survival limit, in area, extensively absorbs and integrates new modeling elements and artistic, softens the environment space of the lines with rich form and becomes indispensable decorative element in people's daily life. Yimeng modern cloth art works appear various forms, such as curtains, wall hanging, bedspread, cushion, sofa, table cloth, paper tissue box, locker, etc.. In term of functions, the modern cloth art works can be divided home furnishing cloth art works, cloth for car decoration and cloth works for appreciation.

\section{REGIONAL ART CHARACTERISTICS}

\section{A. Various Forms of Art}

Yimeng area's folk handcrafts are rich in resources, in many art forms. There are common dozen varieties, from the traditional embroidery, printing and dyeing cloth, clothing and toys to modern decorative fabric cloth emerging in recent years. They are very popular across Yimeng, covering almost all areas of the local people's material and spiritual life.

\section{B. Simple Natural Materials}

The Yimeng folk cloth handcrafts use pieces left form tailoring, all kinds of silk line, cotton, plant fibers and seeds as material. It is very easy o get them. Such materials are natural and environmental friendly. Besides not only a unique aesthetic value, some materials also have natural aromatic insecticide, refreshment and tranquilization and other health benefits.

\section{Rich Creative Themes}

The Yimeng folk handcrafts have abundant creation theme. Flowers, birds and fish in the nature, landscapes and figures, myths, legends, folk tales, historical figures and a variety of traditional folk auspicious patterns derived from nature can be common theme and content..

\section{Distinctive Craft Features}

The Yimeng folk cloth handcrafts have extraordinary craft features due to different workmanship and skill. Yimeng cloth toys are famous for their vivid, beautiful decoration with very local traditional decorative means. Yimeng embroidery works have complicated and exquisite needle skill and fruitful designs and patterns. Yimeng blueprint cloth and color printing cloth are based on plate making and superb stencil dyeing process to form a rigorous composition, beautiful patterns, clear and bright lines, colorful fresh typical artistic characteristics.

\section{HUMAN CONNOTATION}

As epitome of Yimeng area, the Yimeng folk cloth handcrafts have a long history and splendid culture. In the long-term development it has been blended into the local history and culture, outstanding character, customs and habits of Yimeng people, thus expressing extremely rich regional cultural connotation.

\section{A. Rich Historical and Cultural Connotation}

Yimeng area has a long history and talented people, and it is one of the important birthplaces of Chinese civilization. As early as 400,000 years and 500,000 years ago, the ancestors of Yimeng created rich prehistoric culture on this land, such historic figures as the inventor of the abacus Liu Hong in 
Eastern Han dynasty, the military strategist Zhuge Liang from the Three Kingdoms Period, the calligrapher sage Wang Xizhi in the Eastern Jin Dynasty lived here and left lots of deep cultural imprint. The long history and profound cultural accumulation, while raising the diligence and wisdom of the Yimeng people, have cultured deeply the Yimeng folk cloth handcrafts. The Yimeng textile technology has a long history which originated in the Neolithic Age have begun to sprout, dating back to more than four or five thousand years ago. The famous Yimeng blue printed cloth and printed cloth have flourished throughout the Qin, Han, Tang, Ming and Qing Dynasties. Its source can be traced back to the Spring and Autumn Period, more than two thousand years ago. The folk embroidery popular in Yishui and Yinan, carrying the local people "pray" good wishes and sincere feelings, so far has gone through more than one thousand years. In addition such Yinan's cloud shoulder and Mengyin tiger cloth have been still flourished in hundreds of years. All highlight the profound historical and cultural heritage and unique charm of Yimeng folk cloth handcrafts.

\section{B. Regional Humanistic Spirit of "Hardworking and Brave, Selfless Dedication"}

Yimeng area [profound historical and cultural heritage and simple folk customs have forged the brave, selfless, and outstanding character of Yimeng people, also gives the Yimeng folk cloth rich humanistic connotation. During the war of resistance against Japan and the liberation war, tens of thousands of Yimeng women joined the mass to support battle in the frontline. They used last wisp of cotton for spinning and weaving, military shoes, insole embroider and sewing clothing, so as to make ordinary folk cloth have a moving humanistic spirit. In times of peace, hardworking and intelligent Yimeng people blend the red spirit of the Yimeng people like the red love of the party and the army and selfless dedication, into the ordinary folk art creation. The local people have created a large number of cloth art works with a Yimeng ethos and the humanities connotation in the new era, such as Mo Zongrong's woolen embroidery work "Menglianggu victory", Zhang MingJian's printed cloth "Welcome the Olympic Games" and "The motherland long live", which are outstanding representatives.

\section{C. "Naive Nature, Advocating Naive" Aesthetic Thinking}

Yimeng mountain area is relatively closed by geographical environment. The people here are simple, far away from the city flashy environment and cultural and historical background. They have formed a folk artist aesthetic idea of "not luxurious, simple and natural". Under the influence of this thought, the Yimeng folk cloth relies on more on pure handicraft making. Its material is also local immediately visible natural material, a piece of cloth, a thread, a cotton ball, so they are handy into works of art. In the decoration methods, the Yimeng folk cloth often is often made according to the material shape, showing a local flavor and" simple and artless naive unique charm. Local folk artists have simple artistic ideas and aesthetic concepts, which have far-reaching impacts on the form and content, and creation technique of cloth handcrafts, thus making the Yimeng folk cloth simple, natural, fresh regional artistic style.

\section{CONCLUSION}

Yimeng area folk cloth handcraft art has a long history, variety of form and content, with distinctive features of the Yimeng and profound value of folk culture. As a folk art, it has permeated every field of people's material and spiritual life, passing Yimeng's history, culture and customs. It has a farreaching influence in local people's life. In the current cultural context, to the Yimeng folk art form and content and the regional characteristics of the research and to explore the art value and humanism spirit have an important practical significance on the excavation of Yimeng culture, heritage protection and outstanding folk arts and crafts.

\section{REFERENCES}

[1] Bao Xiaolong Liu Yuerui "Hand dyeing art" [M]. Donghua University press 2013.4

[2] Yang Li . "On Yimeng mountain folk cloth " [D] China outstanding master's degree thesis database.2008.

[3] Chen Xiaoping "[J]." On the folk embroidery" Art Gallery 2009.7

[4] Liu Fan "A study on the aesthetic characteristics of Chinese folk cloth tiger toys [J] Art \& Design (Theory) 2011.4

[5] Gong Chuhan. "On the folk aesthetic emotion of embroider pouch" [D]. China outstanding master's degree thesis database. 2007.1 